\title{
PENINGKATAN ASPEK PERENCANAAN UNTUK MEWUJUDKAN SEKOLAH EFEKTIF DALAM LEMBAGA PENDIDIKAN ISLAM
}

\author{
Oleh. \\ Sumarto \\ Institut Agama Islam Negeri (IAIN) Curup \\ sumarto.manajemeno@gmail.com
}

\begin{abstract}
The future of schools is largely determined by managerial factors one aspect is planning. Small schools will develop significantly when professionally managed. With the same easy management, large schools will grow. Conversely, advanced schools will experience a setback when management is not well managed. If schools neglect management, small schools will close down in the face of multimensional dimensions. Planning patterns in schools that have not been conducive to face the challenges of modernization even need to be changed into planning patterns that are more responsive to the needs of society and the demands of the times. The pattern must lead to activities that involve more and more people in the leadership ranks, to jointly run the wheels of the school organization towards conditions that are advanced and established, both in terms of institutional, educational system, learning process, and quality of students so that they can realize effective school.
\end{abstract}

\section{Keywords: Planning, Effective Schools and Islamic Education Institutions}

\begin{abstract}
Abstrak
Masa depan sekolah sangat ditentukan oleh faktor manajerial salah satu aspeknya adalah perencanaan. Sekolah kecil akan berkembang secara signifikan manakala dikelola secara profesioanal. Dengan pengelolaan yang samasekolah yang mudah besar akan bertambah besar. Sebaliknya sekolah yang maju akan mengalami kemunduran manakala manajemennya tidak terurus dengan baik. Jika sekolah mengabaikan manajemen, sekolah kecil akan gulung tikar dalam mengahadapi multideimensi. Pola-Pola perencanaan di sekolah yang selama ini kurang kondusif menghadapi tantangan-tantangan moderenisasi bahkan perlu diubah menjadi pola-pola perencanaan yang lebih responsif terhadap kebutuhan masyarakat dan tuntutan kemajuan zaman. Pola tersebut haruslah mengarah pada kegiatan yang melibatkan lebih banyak orang lain lagi dalam jajaran kepemimpinan, untuk bersama-sama menjalankan roda organisasi sekolah menuju kondisi yang maju dan mapan, baik dari sisi kelembagaan, sistem pendidikan, proses pembelajaran, maupun kualitas peserta didik sehingga bisa mewujudkan sekolah efektif.
\end{abstract}

\section{Kata Kunci: Perencanaan, Sekolah Efektif dan Lembaga Pendidikan} Islam 


\section{A. PENDAhuluan}

Menurut Hamdani Hamid, planning adalah pemilihan fakta dan usaha menghubungkan antara fakta yang satu dan yang lain. ${ }^{1}$ Sedangkan menurut Sudjana dalam Din Wahyudin menyatakan bahwa perencanaan adalah proses yang sistematis sesuai dengan prinsip dalam pengambilan keputusan. ${ }^{2}$ Selanjutnya dikatakan oleh E. Mulyasa, perencanaan menyangkut penetapan tujuan, dan kompetensi, serta memperkirakan cara mencapainya. ${ }^{3}$ Ungkapan lain menurut Hamzah B. Uno, dalam bukunya Perencanaan Pembelajaran bahwa perencanaan adalah suatu cara untuk mengantisipasi dan menyeimbangkan perubahan. ${ }^{4}$

Perencanaan strategis adalah salah satu cara untuk membantu organisasi dan komunitas mengatasi lingkungan mereka yang telah berubah, juga dapat membantu organisasi dan komunitas untuk merumuskan dan memecahkan masalah terpenting yang mereka hadapi serta membantu organisasi dan komunitas menjadi lebih efektif. 5

Maisah mengemukakan bahwa perencanaan stratejik adalah bagian

${ }^{1}$ Hamdani Hamid, Pengembangan Kurikulum Pendidikan, (Bandung: Pustaka Setia, 2012),hal. 51.

${ }^{2}$ Dinn Wahyudin, Manajemen Kurikulum, (Bandung: PT. Remaja Rosdakarya, 2014), hal. 81.

${ }^{3}$ E. Mulyasa, Standar Kompetensi dan Sertifikasi Guru, (Bandung: Remaja Rosdakarya, 2008), hal. 77.

${ }^{4}$ Hamzah B. Uno, Perencanaan Pembelajaran, Cet. 7, (Jakarta: Sinar Grafika, 2011), hal. 1.

${ }^{5}$ Jhonm. Bryson. Perencanaan Strategis. (Yogyakarta: Pustaka Pelajar. 2007), hal. 24. dari proses manajemen stratejik pendidikan. Mencakup empat tugas utama yaitu melakukan evaluasi situasi internal dan eksternal. Dalam rangka menyusun perencanaan strategi SDM ada beberapa tantangan yang menonjol yang harus diperhatikan yaitu bagaimana: 1. Memelihara keunggulan kompetitif yang dimiliki organisasi pendidikan, 2. Memperkuat strategi pendidikan secara keseluruhan, 3. Mencegah konsentrasi yang berlebihan terhadap masalah sehari-hari, 4. Mengembangkan strategi SDM yang dapat memenuhi kebutuhan khusus pendidikan, 5. Menghadapi kondisi lingkungan yang penuh perubahan, 6 . Memantapkan komitmen manajemen, 7. Menerjemahkan rencana strategi ke dalam tindakan, 8. Mengkombinasikan strategi yang diinginkan dan yang muncul mendadak, 9. Mengakomadasikan perubahan. ${ }^{6}$

Perencanaan dalam arti luas adalah proses mempersiapkan kegiatan secara sistematis yang dilakukan untuk mencapai tujuan. Perencanaan itu sebagai suatu proses pembuatan serangkaian kebijakan untuk mengendalikan masa depan sesuai yang ditentukan. Perencanaan memiliki peranan penting dan mendasar, karena perencanaan melihat jauh ke depan dan mewujudkan berbagai cita-cita yang diharapkan. Dengan begitu peranan perencanaan menjadi sentral dalam suatu organisasi.

Perencanaan dari sistem pengelolaan dalam pendidikan Islam,

${ }^{6}$ Maisah, Manajemen Starategik dalam Persfektif Pendidikan Islam, (Jambi: Salim Media Indonesia, 2016), hal. 42-43. 
adalah merupakan langkah pertama yang harus diperhatikan oleh para pengelola pendidikan Islam. Sebab sistem perencanaan yang meliputi penentuan tujuan dan target pendidikan Islam harus didasarkan pada kondisi sumber daya yang dimiliki.Perlu diadakan penelitian secara akurat. Kesalahan dalam menentukan perencanaan dalam pendidikan Islam, akan berakibat sangat fatal bagi kelangsungan pendidikan Islam. Perencanaan tersebut harus tersusun secara rapi, sistematis dan rasional, agar muncul pemahaman yang cukup mendalam terhadap perencanaan itu sendiri.

$\begin{array}{ccr}\text { Salah } & \text { satu } & \text { klasifikasi } \\ \text { perencanaan } & \text { adalah } & \text { rencana } \\ \text { pengembangan.Rencana } & \text { tersebut }\end{array}$
menunjukkan arah (secara grafis) tujuan dari organisasi.Cara rasional untuk mengetahui pengembangan yang diinginkan itu ialah berdasarkan sepakat para anggota manajemen yang berwenang dalam menentukan pengembangan dan perencanaan yang mendukung pencapaian pengembangan tersebut. $^{7}$

Untuk itu diperlukan pengetahuan tentang posisi organisasi, arah tujuannya dan sasaran yang harus dicapai; masalah-masalah yang sedang atau akan dihadapi dalam rangka pencapaian tujuannya; timing untuk melaksanakan pengembangan rencana dan kegiatan-kegiatan khusus perlu dilaksanakan untuk mencapainya.

${ }^{7}$ George R. Terry, Prinsip-Prinsip Manajemen, (Jakarta: Bumi Aksara, 2009), hal. 60.
Agar

perencanaan

menghasilkan rencana yang baik, dan realistis maka kegiatan perencanaan perlu memperhatikan 1) keadaan sekarang; 2) keberhasilan dan faktor kritis keberhasilan; 3) kegagalan masa lampau; 4) potensi, tantangan yang ada; 5) kemampuan merubah kelemahan menjadi kekuatan, dan ancaman menjadi peluang; 6) mengikutsertakan pihakterkait; 7) memperhatikan komitmen dan mengoordinasikan pihak terkait; 8) mempertimbangkan efektivitas dan efisiensi, demokratis, transparan, realistis, legalitis, \& praktis; 9) mengujicobakan kelayakan perencanaan.

\section{B. PEMBAHASAN}

\section{Perencanaan}

Perencanaan juga sebuah proses perdana ketika hendak melakukan pekerjaan baik dalam bentuk pemikiran maupun kerangka kerja agar tujuan yang hendak dicapai mendapatkan hasil yang optimal. Perencanaan adalah salah satu fungsi awal dari aktivitas pengelolaan dalam mencapai tujuan secara efektif dan efisien.Suatu perencanaan yang efektif merupakan aktifitas yang sangat penting dalam organisasi.Hal ini agar setiap individu/kelompok dapat bekerja sesuai dengan tujuan yang direncanakan dan diharapkan.Dengan demikian perencanaan perlu dipahami dengan baik.

Dalam konteks ini perencanaan (planning) didefinisikan Hill dan Mc Shane: Planning is a process whereby managers select goals, choose actions (strategies) to attain those goals, 
allocate responsibility for implementing actions to specific individual or units, measure the success of actions by comparing actual results against the goals, and revise plan accordingly. ${ }^{8}$ menurut definisi ini perencanaan adalah proses dimana manajer menyeleksi tujuan/sasaran, memilih tindakan (strategi) untuk mencapai tujuan, mengalokasikan tanggungjawab mengimplementasikan tindakan itu kepada orang atau unit tertentu. Mengatur kesuksesan tindakan dengan membandingkan hasil actual terhadap tujuan, dan merevisi rencana itu dengan tepat.

Mejia dan David, mengemukakan, a process that helps managers set objectives for the future and map out the activities and means that will make it possible to achieve those objectives. ${ }^{9}$ Perencanaan dalam pengertian ini adalah merupakan suatu proses yang membantu manajer menetapkan tujuan untuk masa yang akan datang dan memetakan aktivitas dan sarana yang memungkinkan untuk mencapai tujuan tersebut.

Berdasarkan dua definisi di atas, ada empat unsur penting dalam setiap perencanaan: 1) tujuan adalah sasaran atau target yang ingin dicapai organisasi dalam waktu tertentu; 2) tindakan/strategi adalah langkahlangkah khusus yang diambil organisasi untuk mencapai tujuan yang diinginkan; 3) alokasi sumber daya,

8 Hill, Charles, W. L. \& Steven L. McShane, Principles of Management (Boston: McGraw-HillIrwin, 2008), hal. 106.

9 Gomez-Mejia dan David B. Balkin, Management; People, Performance, Change (Boston: Prentic Hall, 2012), hal.134. tindakan yang direncanakan tidak dapat dijalankan tanpa alokasi sumber daya yang dicermati; 4) implementasi, rencana harus disertai dengan pedoman implementasi yang menunjukkan bagaimana tindakan-tindakan itu akan dilaksanakan. Implementasi meliputi pembagian tugas di antara pelaksana yang berbeda, dan menjelaskan batas waktu penyelesaian.

\section{Pengelolaan Sekolah}

Pendapat lain tentang perencanaan Syafaruddin memberikan definisi perencanaan adalah pandangan masa depan dan menciptakan kerangka kerja untuk mengarahkan tindakan seseorang di masa depan. ${ }^{10}$ Ismaya menyebutkan: Perencanaan dapat didefinisikan sebagai proses dimana manajer satu tujuan, menilai masa depan, dan mengembangkan tindakan yang dirancang untuk mencapai tujuan tersebut.

Dalam setiap perencanaan selalu terdapat tiga kegiatan yang meskipun dapat dibedakan, tetapi tidak dapat dipisahkan antara satu dengan yang lainnya dalam proses perencanaan. Ketiga kegiatan itu adalah: 1) perumusan tujuan yang ingin dicapai; 2) pemiihan program untuk mencapai tujuan itu; 3) identifikasi dan pengarahan sumber yang jumlahnya selalu terbatas. ${ }^{11}$ Perencanaan yang baik dilakukan untuk mencapai: 1) "Protective benefits" yaitu menjaga agar tujuan-tujuan, sumber dan

10 Syafarudin dan Irwan Nasution, Manajemen Pembelajaran (Jakarta: Quantum Teaching, 2005), hal. 77.

${ }^{11}$ Nanang Fatah. Landasan Manajemen Pendidikan (Bandung: PT Remaja Rosdakarya. 2008), hal. 24 
teknik/metode memiliki relevansi yang tinggi dengan tuntutan masa depan sehingga dapat mengurangi resiko keputusan. 2) "Positive benefits" yaitu produktivitas dapat meningkat sejalan dengan dirumuskannya rencana yang komprehensif dan tepat. ${ }^{12}$

Perencanaan menurut Usman, proses mempersiapkan kegiatankegiatan secara sistematis yang akan dilaksanakan untuk mencapai tujuan tertentu. perencanaan adalah perhitungan dan penentuan tentang sesuatu yang akan dijalankan dalam rangka mencapai tujuan tertentu, siapa yang melakukan, bilamana, dimana, dan bagaimana caranya. Sejala dengan penjelasan Hasibuan bahwa: Perencanaan adalah proses penentuan tujuan dan pedoman pelaksanaan dengan memilih yang terbaik dari alternatif-alternatif yang ada. ${ }^{13}$

Dalam kerangka pengelolaan sekolah, perencanaan merupakan keseluruhan proses pemikiran penentuan secara matang terhadap halhal yang akan dikerjakan pada masa yang akan datang dalam rangka mencapai tujuan yang telah ditentukan. Merencanakan suatu kegiatan merupakan suatu tindakan awal sebagai pengakuan bahwa suatu pekerjaan tidak semata-mata ditentukan sendiri keberhasilannya, namun banyak faktor lain yang harus dipersiapkan untuk mendukung keberhasilannya.

\section{Pandangan Islam}

12 Engkoswara Dan Aan Komariah, Administrasi Pendidikan (Bandung: ALFABETA, 2012), hal. 133.

13 Malayu S.P. Hasibuan, Manajemen Dasar, Pengertian, dan Masalah, cet xi (Jakarta: PT. Bumi Aksara, 2016), hal. 40.
Mengenai pentingnya suatu perencanaan, ada beberapa konsep yang tertuang dalam Alquran dan Alhadits. Di antara ayat Alquran yang terkait dengan fungsi perencanaan adalah: Surat Al-Hasyr ayat 18 sebagai berikut: ${ }^{14}$

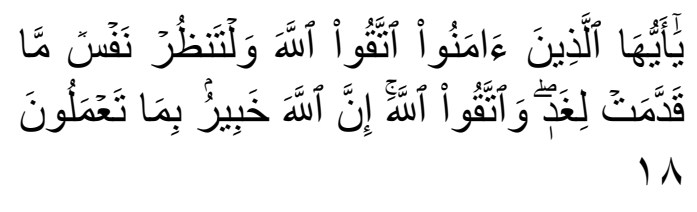

Artinya:

Hai orang-orang yang beriman, bertakwalah kepada Allah dan hendaklah Setiap diri memperhatikan apa yang telah diperbuatnya untuk hari esok (akhirat); dan bertaqwalah kepada Allah, sesungguhnya Allah maha mengetahui apa yang kamu kerjakan. (Q.S. Al-Hasyr. 18).

Menurut Ibnu Katsir bahwa yang dimaksud dengan kalimat Allah:

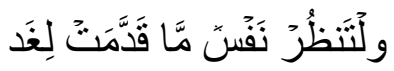

hendaklah masing-masing individu mempersiapkan melakukan amal-amal shalih untuk hari kamu kembali dan hari kamu bertemu Tuhanmu. ${ }^{15}$

Ayat di atas menjadi inspirasi bagi pengelola sekolah untuk selalu menyusun perencanaan, sebagai landasan utama bagi motivasi manusia, suatu kesadaran untuk berkarya dalam arti tujuan-tujuan dan sasaran-sasaran yang telah dikenal untuk mencapai tujuan yang diinginkan, sehingga

${ }^{14}$ Departemen Agama RI, Al-quran dan Terjemahannya Al Hasyr : 18.

15 Abu Al-Fida'Ismailibnu Umar AlDimasqa, Tafsir Al Quran Juz 8 (Mauqiul Al Islam: Dalam sofwer Makhtabah Syamilah, 2005), hal. 88. 
dengan aktivitas yang didasarkan pada niat yang baik dengan keimanan yang benar, para pengelola di sekolah mendapat nilai plus dari Allah SWT.

Seiring dengan penjelasan ayat di atas, Rasulullah SAW, pernah menjelaskan tentang sugesti amal yang mendapat nilai yang baik sesuai dengan niat yang diputuskan di awal aktivitasnya. Sesuai dengan Haditsberikut: ${ }^{16}$ Artinya:Hadits

Humaidi Abdullah Ibn Zubair, katanya Hadits Sufyan, katanya Hadits Yahya Ibn Sa'id Al-Anshari, katanya Muhammad Ibrahim At-Taimy memberitakan katanya, bahwa ia mendengar Al-Qamah Ibn Waqqas AlLaisi berkata ia mendengar Umar Ibn Khattab r.a. berbicara diatas mimbar, katanya aku mendengar Rasulullah SAW bersabda: segala perbuatan hanya bergantung pada niat. Setiap orang hanya memperoleh sesuai dengan niatnya.Maka siapa yang hijrah karena Allah dan Rasul-Nya.Dan yang berhijrah karena dunia atau perempuan yang dinikahinya, maka hasil hijrahnya sesuai dengan apa yang diniatkannya." (HR. Bukhari).

Ayat Alquran dan Hadits Nabi di atas adalah sebagai argumen yang menjelaskan bahwa setiap usaha yang dilaksanakan terlebih dahulu menyusun sebuah rencana yang matang.Terlebih utama lagi dalam bidang pendidikan yang menuntut para pengelola untuk benar-benar menyusun sebuah rencana dapat mengakomodasi kepentingan semua pihak. Sebab, bila salah dalam

16 Muhammad Fu'ad Bin Abdul Baqi, Mutiara Hadits Shahih/Al-lu'lu Wal Marjan (Surabaya: PT. Bina Ilmu, 2005), hal. 1-2. penyusunan rencana akan berdampak negatif terhadap penyelenggaraan pendidikan.

Perencanaan yang baik akan dicapai dengan mempertimbangkan kondisi di waktu yang akan datang dalam mana perencanaan dan kegiatan yang akan diputuskan akan dilaksanakan, serta periode sekarang pada saat rencana di buat. Perencanaan merupakan aspek penting dari pada pengelolaan. Keperluan merencankan ini terletak pada kenyataan bahwa manusia dapat mengubah masa depan menurut kehendaknya.

Manusia tidak boleh menyerah pada keadaan dan masa depan yang menentu tetapi menciptakan masa depan itu. Masa depan adalah akibat dari keadaan masa lampau. Keadaan sekarang dan disertai dengan usahausaha yang akan dilaksanakan. Veithzal menjelaskan: perencanaan adalah hubungan antara apa yang ada sekarang (what is) dengan bagaimana seharusnya (what should be) yang berhubungan dengan kebutuhan, penentuan tujuan, prioritas, program, dan alokasi sumber. Bagaimana seharusnya adalah mengacu pada masa yang akan datang. Perencanaan di sini menekankan kepada usaha mengisi kesenjangan antara keadaan sekarang dengan keadaan yang akan datang disesuaikan dengan apa yang akan dicita-citakan, ialah menghilangkan jarak antara keadaan sekarang dengan keadaan mendatang yang diinginkan. ${ }^{17}$

17 Veithzal Rivai dan Sylviana Murni, Education Management Analisis Teori dan Praktik (Jakarta: Rajawali Press, 2009), hal. 106. 
Perencanaan merupakan siklus tertentu dan melalui siklus tersebut suatu perencanaan bisa dievaluasi sejak awal persiapan sampai pelaksanaan dan penyelesaian perencanaan. Secara umum ada beberapa langkah penting dalam suatu perencanaan yang baik: 1) tujuan secara lengkap dan jelas; 2) adanya rumusan kebijakan, yang menyesuaikan antara tindakan-tindakan dengan faktor lingkungan, apabila tujuan itu tercapai; 3) analisi dan penetapan cara dan sarana untuk mencapai tujuan; 4) penunjukan orang yang akan menerima tanggung jawab pelaksanaan; 5) penentuan sistem pengendalian yang memungkinkan pengukuran dan pembandingan apa yang harus dicapai, dengan apa yang telah dicapai, berdasarkan kriteria yang sudah ditetapkan. ${ }^{18}$

\section{Sekolah Efektif terwujud dengan Perencanan}

Sekolah efektif terwujud dengan adanya perencaan yang baik, perencanaan adalah kemampuan manusia secara sadar memilih alternatif masa depan yang akan dikehendakinya dan kemudian mengarahkan daya upayanya untuk mewujudkan masa depan yang dipilihnya, dalam hal ini manajemen yang akan diterapkan seperti apa, sehingga dengan dasar itulah maka suatu rencana akan terealisasikan dengan baik. Adapun kegunaan perencanaan adalah sebagai berikut: 1) Perencanaan meliputi usaha untuk memetakan tujuan atau memformulasikan tujuan yang dipilih

\footnotetext{
18 Onisimus Amtu, Manajemen Pendidikan di Era Otonomi Daerah (Bandung: Alfabeta, 2013), hal. 45.
}

untuk dicapai, maka perencanaan haruslah bisa membedakan poin pertama yang akan dilaksanakan terlebih dahulu. 2) Dengan adanya perencanaan maka memungkinkan kita mengetahui tujuan-tujuan yang akan di capai. 3) Dapat memudahkan kegiatan untuk mengidentifikasikan hambatanhambatan yang akan timbul dalam usaha mencapai tujuan.

Suatu contoh perencanaan yang gemilang dan terasa sampai sekarang adalah peristiwa khalwat dari Rasulullah di gua hira.Tujuan Rasulullah SAW berkhalwat dan bertafakkur dalam gua Hira ${ }^{\text {ee }}$ tersebut adalah untuk mengidentifikasi masalah yang terjadi pada masyarakat Mekkah.Selain itu, beliau juga mendapatkan ketenangan dalam dirinya serta obat penawar hasrat hati yang ingin menyendiri, mencari jalan memenuhi kerinduannya yang selalu makin besar, dan mencapai ma'rifat serta mengetahui rahasia alam semesta.

Pada usia 40 tahun, dalam keadaan khalwat Rasulullah SAW menerima wahyu pertama. Jibril memeluk tubuh Rasulullah SAW ketika beliau ketakutan.Tindakan Jibril tersebut merupakan terapi menghilangkan segala perasaan takut yang terpendam di lubuk hati beliau.Pelukan erat itu mampu membuat Rasulullah SAW tersentak walau kemudian membalasnya.Sebuah tindakan refleks yang melambangkan sikap berani.Setelah kejadian itu, Rasulullah SAW tidak pernah dihinggapi rasa takut, apalagi bimbang dalam menyebarkan Islam ke seluruh pelosok dunia. Contoh lain dari 
perencanaan yang dilakukan Rasulullah SAW dapat ditemukan ketika terjadi perjanjian Hudaibiyyah (shulhul Hudaibiyyah). Dari perjanjian tersebut terkesan Rasulullah SAW kalah dalam berdiplomasi dan terpaksa menyetujui beberapa hal yang berpihak kepada kafir Quraisy.Kesan tersebut ternyata terbukti sebaliknya setelah perjanjian tersebut disepakati. Disinilah terlihat kelihaian Rasulullah SAW dan pandangan beliau yang jauh ke depan. Rasulullah SAW adalah insan yang selalu mengutamakan kebaikan yang kekal dibandingkan kebaikan yang hanya bersifat sementara. Walaupun perjanjian itu amat berat sebelah, Rasulullah SAW menerimanya karena memberikan manfaat di masa depan saat umat Islam berhasil membuka kota Mekkah (fath al Makkah) pada tahun ke-8 Hijriyah (dua tahun setelah perjanjian Hudaibiyah).

Untuk menjamin tercapainya hasil akhir dari perencanaan, kepala sekolah harus berpijak pada data yang akurat dan cermat.Rencana memberikan arah sasaran bagi organisasi atau sekolah dan mencerminkan prosedur terbaik untuk mencapai sasaran tersebut. Selain itu rencana memungkinkan: 1) sekolah dapat memperoleh serta mengikat sumber daya yang diperlukan untuk mencapai tujuan; 2) anggota organisasi dapat melanjutkan kegiatan-kegiatan secara konsisten dengan tujuan prosedur yang telah dipilih dan; 3) kemajuan dapat dipantau dan diukur sehingga tindakan perbaikan dapat diambil apabila kemajuan itu tidak memuaskan. ${ }^{19}$

Kepala sekolah mesti menyusun dan merumuskan perencanaan dengan tepat. Setiap sekolah memerlukan adanya strategi dengan menyusun tujuan, visi, misi, sasaran, metode, program dan kegiatan yang akan dilakukan untuk mencapai tujuan tersebut. Baik jangka pendek maupun jangka panjang.Dalam hal ini dibutuhkan analisis SWOT yaitu mengenai kekuatan, kelemahan, peluang, dan tantangan. Untuk itu memerlukan tim kerja baik pimpinan sekolah, guru-guru masyarakat serta stake holder yang ada sehingga dapat ditampung inspirasi tentang masa depan sekolah sebagaimana yang diharapkan.

Prinsip-prinsip yang harus diperhatikan dalam menyusun/membuat perencanaan: 1) Harus benar-benar membantu tercapainya tujuan (retribun to purpose and objective); 2) Dilakukan pada semua tingkat, mulai dari pimpinan sampai ketingkat bawahan yang sesuai dengan lingkup kegiatan yang dilakukan (pervasiveness of planning); 3) Mempunyai nilai-nilai efesiensi yang tinggi (efficiency of planning). ${ }^{20}$ Disamping itu ada tiga pendekatan yang harus digunakan dalam perencanaan pendidikan: 1) Pendekatan "social demand" yaitu dikaitkan dengan tuntutan masyarakat; 2)

19 Sudarwan Danim, Suparno, Pengelolaan Kepemimpinan Transformasional KeKepala Sekolahan (Jakarta: Rineka Cipta, 2009), hal. 9.

20 Asnawir, Manajemen Pendidikan (Padang: IAIN IB Press, 2007), hal, 60. 
Pendekatan " Man power" yaitu dikaitkan dengan pengembangan tenaga melalui pendidikan untuk memenuhi disektor ekonomi; 3) Pendekatan "cost beneft" yaitu pendekatan mempertimbangkan keuntungan yang diperoleh melebihi pengeluaran anggaran pendidikan. ${ }^{21}$

Dalam perencanaan ini didapatkan visi sekolah, misi sekolah, tujuan sekolah dan rencana kerja sekolah.Artinya setiap sekolah wajib merumuskan dan menetapkan serta mengembangkan visi, misi, tujuan dan rencana kerja sekolahnya sesuai dengan kriteria dan ketentuan yang telah ditetapkan tersebut.

Semua sekolah dituntut untuk membuat rencana kerja baik menengah ataupun tahunan. Rencana kerja: 1) rencana kerja jangka menengah yang menggambarkan tujuan yang akan dicapai dalam waktu empat tahunan yang berkaitan dengan mutu lulusan yang ingin dicapai dan perbaikan komponen yang mendukung peningkatan mutu lulusan; 2) rencana kerja tahunan yang dinyatakan dalam rencana kegiatan dan anggaran sekolah dilaksanakan berdasarkan rencana jangka menengah. $^{22}$

Dalam perencanaan sekolah unggulan membutuhkan pendekatan rasional ke arah tujuan yang telah ditetapkan.Namun demikian, pada prinsipnya dalam perencanaan strategis harus menghasilkan sebuah analisis lingkungan strategis baik eksternal maupun internal. Perumusan strategis meliputi pengembangan visi, misi dan

${ }^{21}$ Ibid, hal. 60 .

${ }^{22}$ Ibid, hal. 8 . mengidentifikasi lingkungan eksternal (peluang dan ancaman), lingkungan internal (kekuatan dan kelemahan), menetapkan tujuan jangka panjang, mengumpulkan alternatif, serta memilih strategi-strategi khusus yang akan diberlakukan dalam menangani masalah di sekolah. ${ }^{23}$

\section{Berdasarkan Permandiknas}

Nomor 19 Tahun 2007 tentang standar pengelolaan pendidikan oleh satuan pendidikan dasar dan menengah, perencanaan program ditandai dengan kegiatan berupa perumusan visi, misi, tujuan, serta rencana kerja sekolah. ${ }^{24}$

\section{Visi Sekolah}

Visi sekolah merupakan acuan yang digunakan sebagai cita-cita bersama warga sekolah dan segenap pihak yang berkepentingan pada masa yang akan datang. Secara sederhana, visi dapat diartikan sebagai pandangan, keinginan, cita-cita, harapan dan impian tentang masa depan. ${ }^{25}$ Visi pada dasarnya bukanlah sekedar penglihatan kasat mata melainkan suatu pengelihatan yang didasari kekuatan mental batiniah dalam cakupan kognitif, afektif, konatif dan psikomotorik. Sagala, mendefinisikan visi adalah daya pandang yang jauh mendalam dan meluas yang merupakan daya pikir abstrak; memiliki kekuatan

23 Juliansyah Noor, Penelitian Ilmu Manajemen, Tinjauan Filosofis dan Praktis (Jakarta: Kencana Prenada grop, 2013), hal. 124.

${ }^{24}$ Kemendiknas.Peraturan Menteri Pendidikan Nasional Nomor 19 Tahun 2007 Tentang Standar Pengelolaan Pendidikan.

25 Marno dan Triyo Supriyatno, Manajemen dan Kepemimpinan Pendidikan Islam (Bandung: PT Refika Aditama, 2008), hal. 55. 
yang dahsyat dan dapat menerobos segala batas-batas fisik, waktu, dan tempat juga diartikan adalah tindakan, kekuatan, kecakapan atau kemampuan melihat dan memahami untuk berimajinasi dalam mempersiapkan masa datang ${ }^{26}$

Visi sekolahmerupakan tujuan jauh yang harus dicapai oleh sekolahdalam kurun waktu tertentu. Dengan ditetapkannya tujuan -tujuan tersebut, maka seluruh komponen lembaga akan diarahkan ke arah tujuan tersebut. Sekolah yang tidak memiliki visi, belum memiliki acuan kerja, maka setiap komponen sekolahtersebut akan bergerak ke arah yang menjadi visinya sendiri-sendiri, sehingga sekolahtersebut tidak punya arah karena setiap komponen menentukan arahnya sendiri. $^{27}$

Dapat disimpulkan, visi sekolah adalah agenda tujuan yang terdiri dari golongan (thrust), ruang lingkup, persyaratan, prioritas, implikasi, tindakan, kekuatan, kecakapan atau kemampuan melihat dan memahami untuk berimajinasi dalam mempersiapkan masa mendatang. Visi sekolah pada hakekatnya adalah statemen fundamental (fundamental statement) mengenai nilai, aspirasi, dan tujuan institusi madrasah.Oleh karena itu visi sekolah merupakan kunci

${ }^{26}$ Syaiful Sagala, Manajemen Strategik dalam Peningkatan Mutu Pendidikan (Bandung: Alfabeta, 2013), hal. 134.

${ }^{27}$ Muhaimin, Suti'ah dan Sugeng Listyo Prabowo, Manajemen Pendidikan: Aplikasinya dalam Penyusunan Rencana Pengembangan Sekolah/Madrasah (Jakarta: Kencana, 2009), hal. 155-157. keberhasilan sebuah lembaga sekolah yang dikelola secara profesional.

Setelah dirumuskan visi, maka visi dikembangkan dalam misi, misi yang jelas akan memberikan arah dalam jangka panjang, sehingga memberikan stabilitas manajemen kepemimpinan sekolah.Mendefinisikan misi lembaga pendidikan merupakan hal penting dalam penyelenggaraan lembaga pendidikan tersebut, sebab misi tersebut membatasi operasional dengan penekanan program pada kualitas yang dipersyaratkan dan mencegah organisasi dari mengabaikan hal-hal yang berkaitan dengan ikhtiar bidang usaha, tetapi fokus pada prioritas. $^{28}$

Menurut Muktar hal yang penting diperhatikan dalam menjabarkan misi harus didukung dengan strategi kualitas jangka panjang yang baik dan tujuan dari institusi tersebut harus dapat disampaikan dengan jelas. $^{29}$ Sejalan dengan pendapat Akdon dalam pernyataan misi itu harus: 1) menunjukkan secara jelas mengenai apa yang hendak dicapai oleh organisasi/lembaga; 2) secara eksplisit mengandung apa yang harus dilakukan untuk mencapainya; 3) mengundang partisipasi masyarakat luas terhadap perkembangan bidang

28 Chusnul Chotimah \& Muhammad Fathurrohman, Komplemen Manajemen Pendidikan Islam: Konsep Integratif Pelengkap Manajemen Pendidikan Islam (Yogyakarta: Teras, 2014), hal. 12

29 Mukhtar Latif, Orientasi Baru Supervisi Pendidikan (Jakarta: Gaung Persada Press, 2009), hal. 19 
utama yang digeluti organisasi/

Dapat disimpulkan bahwa misi itu merupakan penjabaran dari visi, menjelaskan tentang tujuan-tujuan yang hendak dicapai, menggambarkan hal-hal yang harus dilakukan untuk mencapai tujuan, pernyataan misi dapat mencerminkan tentang segala sesuatunya untuk mencapai visi. Visi dan misi sekolah harus merupakan konsesus pimpinan (eksekutif) maupun personal sekolah lainnya dan masyarakat yang terkait dengan sekolah sehingga semua elemen penyelenggara sekolah mudah memahami ide-ide dasar visi, misi dan tujuan yang hendak dicapai.

Langkah selanjutnya adalah merumuskan tujuan sekolah yaitu menggambarkan tingkat kualitas yang perlu dicapai dalam jangka menengah (skala empat tahunan). Tujuan dan sasaran merupakan arah atau keadaan yang akan diupayakan untuk dicapai sekolahdalam kurun waktu sedang dan pendek. Dalam penyusunan tujuan dan sasaran harus memperhatikan skala prioritas. Penyusunan skala prioritas yang salah akan menghambat ketercapaian visi dan pemborosan sumber daya. Masing-masing tujuan kemudian dapat dikembangkan menjadi sasaran yang dicapai oleh unit atau bagian. Menurut Muhaimin, dkk, teknik penulisan tujuan dan sasaran harus dinyatakan dalam kalimat yang disusun dengan metode SMART (Spesifik, Measurabel, Attainabel, Responsible, Time framer), artinya

30 Akdon, Strategic Management (Bandung: Alfabeta, 2011), hal. 98 kalimat tujuan dan sasaran harus dirumuskan secara jelas, dapat diukur, berdasar sumber daya yang ada, ada penanggung jawab dan memiliki kerangka waktu).

Perencanaan dalam pengelolaan sekolah unggulan dalam perumusan visi, misi, tujuan pendidikan. Engkoswara, ${ }^{31}$ mendefinisikan: a) visi adalah gambaran-gambaran masa depan yang ideal yang dibentuk anggota sekolah berdasarkan visi peribadi/individu, yang menantang dari keadaan yang diinginkan dan untuk menjamin kelangsungan hidup sekolah; b) misi merupakan rumusan umum mengenai tindakan atau upaya-upaya yang akan dilaksanakan untuk mewujudkan visi. Misi yang jelas akan sangat membatu pencapaian tujuan yang efektif, bermutu, akuntabel dan mampu memberikan kepuasan masyarakat, termasuk di dalamnya efesiensi penggunaan anggaran; c) nilai, yaitu menjelaskan bagaiman cara kita melakukan tugas masing-masing untuk mencapai misi organisasi/ sekolah. Nilai ini harus dijabarkan sepenuhnya dalam sikap dan perilaku sehari-hari, dalam perumusan visi, misi dan nilai dalam satu organisasi/ sekolah.

\section{KESIMPULAN}

Dari penjelasan di atas dapat disimpulkan untuk mewujudkan sekolah efektif harus adanya perencaan dengan proses intelektual yang berkesinambungan dalam

31 Engkoswara dan Aan Komariah, Administrasi Pendidikan (Bandung: Alfabeta, 2012), hal. 137. 
menganalisis, merumuskan, dan menimbang serta memutuskan dengan keputusan yang diambil harus mempunyai konsistensi (taat asas) internal yang berhubungan secara sistematis dengan keputusan-keputusan lain, baik dalam bidang-bidang itu sendiri maupun dalam bidang-bidang lain dalam pembangunan, dan tidak ada batas waktu untuk satu jenis kegiatan, serta tidak harus selalu satu kegiatan mendahului dan didahului oleh kegiatan lain.

Proses perumusan tujuan sekolah mengacu pada visi, misi dan tujuan pendidikan nasional serta relevan dengan kebutuhan masyarakat, standar kompetensi lulusan yang sudah ditetapkan oleh sekolah dan pemerintah, serta mengakomodasi masukan dari berbagai pihak yang berkepentingan termasuk komite sekolah dan diputuskan oleh rapat dewan pendidik yang dipimpin oleh kepala sekolah, disosialisasikan kepada warga sekolah dan segenap pihak yang berkepentingan.

Perencanaan program sekolah efektif merupakan titik awal untuk menjalankan pengelolaan sebuah sekolah. Oleh karena itu perencanaan harus memiliki indikator: 1) mempersiapkan sekolah menjadi sekolah unggulan; 2) menetapakan internal sekolah; 3) menetapkan visi sekolah menjadi sekolah unggulan; 4) menetapkan misi sekolah menjadi sekolah unggulan; 5) menetapkan tujuan sekolah menjadi sekolah unggulan; 6) menyusun program kerja sesuai dengan visi, misi, dan tujuan yang telah ditetapkan, (meliputi: input, proses, dan out put).

\section{DAFTAR PUSTAKA}

Abu Al-Fida'Ismailibnu Umar AlDimasqa, Tafsir Al Quran Juz 8 Mauqiul Al Islam: Dalam sofwer Makhtabah Syamilah, 2005

Akdon, Strategic Management Bandung: Alfabeta, 2011

Asnawir, Manajemen Pendidikan Padang: IAIN IB Press, 2007

Chusnul Chotimah \& Muhammad Fathurrohman, Komplemen Manajemen Pendidikan Islam: Konsep Integratif Pelengkap Manajemen Pendidikan Islam Yogyakarta: Teras, 2014

Departemen Agama RI, Al-quran dan Terjemahannya Al Hasyr : 18.

Dinn Wahyudin, Manajemen Kurikulum, Bandung: PT. Remaja Rosdakarya, 2014

E. Mulyasa, Standar Kompetensi dan Sertifikasi Guru, Bandung: Remaja Rosdakarya, 2008

Engkoswara Dan Aan Komariah, Administrasi Pendidikan Bandung: ALFABETA, 2012

Engkoswara dan Aan Komariah, Administrasi Pendidikan Bandung: Alfabeta, 2012

George R. Terry, Prinsip-Prinsip Manajemen, Jakarta: Bumi Aksara, 2009

Gomez-Mejia dan David B. Balkin, Management; People, Performance, Change, Boston: Prentic Hall, 2012

Hamdani Hamid, Pengembangan Kurikulum Pendidikan, Bandung: Pustaka Setia, 2012

Hamzah B. Uno, Perencanaan Pembelajaran, Cet. 7, Jakarta: Sinar Grafika, 2011 
Hill, Charles, W. L. \& Steven L. McShane, Principles of Management Boston: McGrawHillIrwin, 2008

Jhonm. Bryson. Perencanaan Strategis. Yogyakarta: Pustaka Pelajar. 2007

Juliansyah Noor, Penelitian Ilmu Manajemen, Tinjauan Filosofis dan Praktis (Jakarta: Kencana Prenada grop, 2013

Kemendiknas.Peraturan Menteri Pendidikan Nasional Nomor 19 Tahun 2007 Tentang Standar Pengelolaan Pendidikan.

Maisah, Manajemen Starategik dalam Persfektif Pendidikan Islam, Jambi: Salim Media Indonesia, 2016

Malayu S.P. Hasibuan, Manajemen Dasar, Pengertian, dan Masalah, cet xi Jakarta: PT. Bumi Aksara, 2016

Marno dan Triyo Supriyatno, Manajemen dan Kepemimpinan Pendidikan Islam Bandung: PT Refika Aditama, 2008

Muhaimin, Suti'ah dan Sugeng Listyo Prabowo, Manajemen Pendidikan: Aplikasinya dalam Penyusunan Rencana Pengembangan

Sekolah/Madrasah Jakarta: Kencana, 2009

Muhammad Fu'ad Bin Abdul Baqi, Mutiara Hadits Shahih/Al-lu'lu Wal Marjan (Surabaya: PT. Bina Ilmu, 2005

Mukhtar Latif, Orientasi Baru Supervisi Pendidikan Jakarta: Gaung Persada Press, 2009

Nanang Fatah. Landasan Manajemen Pendidikan Bandung: PT Remaja Rosdakarya. 2008
Onisimus Amtu, Manajemen Pendidikan di Era Otonomi Daerah Bandung: Alfabeta, 2013 Sudarwan Danim, Suparno, Pengelolaan Kepemimpinan Transformasional KeKepala Sekolahan Jakarta: Rineka Cipta, 2009

Syafarudin dan Irwan Nasution, Manajemen Pembelajaran Jakarta: Quantum Teaching, 2005 Syaiful Sagala, Manajemen Strategik dalam Peningkatan Mutu Pendidikan Bandung: Alfabeta, 2013

Veithzal Rivai dan Sylviana Murni, Education Management Analisis Teori dan Praktik Jakarta: Rajawali Press, 2009 